\title{
Insurance, Equality and the Welfare State: Political Philosophy and (of) Public Insurance
}

\author{
Xavier Landes $\cdot$ Nils Holtug
}

Published online: 11 March 2015

(C) Springer Science+Business Media Dordrecht 2015

Public insurance is both everywhere and nowhere. It is everywhere in the sense that it is omnipresent in industrialised societies: public health insurance, unemployment benefits and pensions. It is a sizeable part of modern nations' public budget (for many nations like the United States and France about half of it). It has permeated our understanding of societal institutions to the extent that now access to public insurance coverage is understood as being a struggle for equality and equal citizenship (Stone 1999-2000).

Public insurance is only one aspect of a broader phenomenon: the transformation of modern societies into insurance societies, i.e. societies that are orientated toward risk-management (Beck 1992; Ericson and Doyle 2003). Nevertheless, public insurance is at the core of the welfare state as insurance system. Paul Krugman once said of the modern state that it is 'an insurance company with an army' while David Moss (2002) argues that government is the ultimate risk manager (e.g. money emission, banking system, workers protection, disaster relief, and so forth).

At the same time, public insurance is almost nowhere in political philosophy and normative theory (although exceptions include Anderson, Forthcoming; Baker and Moss 2009; Dworkin 2002; Ewald 1996; Heath 2011; Lehtonen and Jyri 2011). Hence, public insurance has attracted little overall interest from political philosophers, especially when compared to redistribution, equality and theories of justice.

The present special issue of Res Publica entitled Insurance, Equality and the Welfare State addresses this lack. It is a contribution to an emerging field that might

\footnotetext{
X. Landes $(\bowtie) \cdot$ N. Holtug

Department of Media, Cognition and Communication, University of Copenhagen, Karen Blixens

Vej 4, 2300 Copenhagen S, Denmark

e-mail: xavier.landes@gmail.com

N. Holtug

e-mail:nhol@hum.ku.dk
} 
be coined the 'political philosophy of public insurance'. The diverse contributions highlight central issues (e.g. individual responsibility, genetic information, equality of status, and public health) and several methodologies (e.g. analytical, sociological) for dealing with public insurance. The aim is to highlight the importance of public insurance for political philosophy in general and for current debates on the welfare state in particular (e.g. rising inequalities).

In this introduction we (1) briefly present reasons why political philosophers have neglected public insurance; (2) briefly characterise what a 'political philosophy of public insurance' could look like; (3) spell out potential research themes; and (4) stress the idea that public insurance is a central issue in the current context of receding welfare states and rising inequalities.

\section{Reasons for Neglect}

Many reasons could be found for why political philosophers have not paid much attention to public insurance. Among them, four in particular seem to us important.

The first reason is a tendency to think that public insurance is a topic of minor importance that does not matter (or does not matter that much) for, for instance, considerations of equality or justice. In other words, public insurance would not really be relevant for political philosophy. Actually, it is difficult to find any good argument in support of this position since it is rather self-evident that specific public insurance programs such as public health or unemployment benefits matter for justice or equality at least on practical grounds.

The second reason is the claim that public insurance is just a tool for other purposes (e.g. justice or equality), and so has instrumental significance at best. This does not imply that insurance is completely irrelevant, only that its relevance is subsumed under more general theoretical frameworks, such as conceptions of justice and equality. A similar point is often made regarding the ethics of taxation: taxation will only be a tool for pursuing an overarching objective (e.g. a society grounded on egalitarian or prioritarian principles of redistribution). Therefore, public insurance would be one tool among others for pursuing broader objectives.

Insurance may of course be used as a tool for pursuing other goals, mainly redistribution. But as a matter of fact, insurance is not inherently a redistributive mechanism, not in the sense that social welfare is. Per se insurance mechanisms are risk-management tools based on risk pooling: individuals pool their resources in order to spread losses. Moreover, insurance delivers most of its benefits (i.e. taming existing risks while avoiding informational problems such as moral hazard or adverse selection) when individual premiums track each policyholder's risk profile (i.e. expected losses) (Landes 2014).

The only redistributive aspect of insurance as a risk-management technology is the partial compensation of the unlucky policyholders by the lucky ones. Insurance is redistributive insofar as it reallocates the outcomes of risks (i.e. losses), but it does not proceed to reallocation of goods, resources or anything else that have been left unaffected by risk. Stated differently, insurance does not change the expected economic value of the individual outcomes (assuming that insurers do not charge an 
extra-cost for profit) where pure redistribution actually does. In short, 'insurance is not fundamentally redistributive at all' (Goodin 1988, p. 159) though it might be bent in a way that makes it more redistributive.

If many public insurance systems are perceived as being redistributive, it is because states set premiums (i.e. individual contributions to insurance) according to citizens' individual ability to pay. Furthermore, premiums often track such abilities indirectly because they are channelled, with other financial contributions, through the general taxation scheme. It is for instance the case when public insurance is financed by income tax.

Thus, insurance mechanisms are not as such redistributive in the sense that mainstream resourcist or welfarist approaches think of redistribution. But the fact that particular insurance arrangements can be bent and used for pursuing various goals does not mean that no specific moral issues arise from insurance mechanisms. For example, insurance mechanisms may frame certain relations of power or advance certain political principles among policyholders. Furthermore, as pointed out above, insurance mechanisms can be rendered redistributive insofar as, for example, premiums track ability to pay while coverage is set by universal principles.

The third reason emphasizes that public insurance is about efficiency and efficiency issues are not moral issues. This distinction actually elaborates on a more or less explicit division of labour between economics and philosophy qua academic disciplines, the former being concerned with efficiency whereas the latter would be devoted to equality.

Despite the cogency of a division of labour between economics and philosophy, it can be argued that efficiency issues are not neutral issues from a moral point of view. First, efficiency judgments require us to define to what efficiency applies. Is the domain of efficiency judgments economic output, material welfare or subjective well-being? Should employment be part of efficiency judgments in the sense that a highly productive society that nevertheless has a high level of unemployment could be judged as efficient? All these judgments should be justified according to an underlying conception of efficiency, which presupposes value judgments.

Second, efficiency judgments require us to define efficiency rules, or conditions for efficiency. In fact, this is the core difference between Pareto and Kaldor-Hicks conceptions of efficiency. The choice between the two conceptions is not morally neutral or trivial, and nor for that matter is the choice between distributive principles that satisfy, for example, the Pareto principle (e.g. utilitarianism, prioritarianism, leximin) and those principles that do not (e.g. maximin, some versions of egalitarianism).

In other words, a preliminary set of normative questions need to be resolved before producing efficiency judgments. Therefore, even to the extent insurance is about efficiency, this does not rule out the need for normative thinking.

\section{A Political Philosophy of Public Insurance}

After addressing reasons for why political philosophy has remained silent on public insurance, the second 'natural' step is to determine how such philosophy may 
contribute to the literature on insurance. What could the main characteristics of a political philosophy of public insurance be? Different answers are possible depending on one's ambitions. Within the limits of this introduction, we simply want to highlight three different conceptions of a political philosophy of public insurance with a special emphasis on the last one since it has been developed the least so far.

A first, modest, idea is to pay more attention in political philosophy to how specific issues of justice and equality could impact public insurance. For instance, an interesting debate could be to determine how prioritarian, sufficientarian or strict egalitarian principles could be accommodated in insurance mechanisms and how these mechanisms in return would influence the implementation of these principles. Kasper Lippert-Rasmussen's contribution to this volume on the use of genetic information for underwriting illustrates this idea.

A second idea is to pay attention to how insurance frames social, economic or power relations (Lehtonen and Jyri 2011). There is an evident link between this conception and Foucault's theoretical framework, exemplified in the work of François Ewald (1986, 1996). Lehtonen and Liukko's contribution to this volume further illustrates this path. Without aiming at a paradigmatic shift, political philosophers may be interested in insurance as a place where specific social or political relations are nurtured by a model exemplified by the work of political philosophers in business ethics (Néron 2010; Norman 2012). If so, this could be another way in which to practice the political philosophy of public insurance.

A third, more ambitious, idea is to inquire into something like an 'inner morality of public insurance'. This approach could be about spelling out the values or principles according to which public insurance would operate, the assumption being that these values or principles are distinct from those in other social domains and are produced by public insurance as a particular kind of cooperative device. Such an inner morality could have implications for justice and equality. This is in a way a reversal of the first conception: instead of trying to figure out what ordinary principles of justice or equality could tell political philosophers about public insurance, it would aim to figure out what public insurance tells us about justice or equality. In fact, there are (at least) two versions of this idea. According to a first, moderate version, this would simply illustrate the way in which, according to a Rawlsian method of reflective equilibrium, political theorists need to go back and forth between principles and intuitions about cases, making revisions in either end, until an equilibrium is found. According to a second, less moderate version, public insurance may be framed as a separate "sphere of justice', to which distinct principles of justice apply (Walzer 1983).

To conclude, no matter which of these three approaches one adopts, there seem to be reasons for devoting more attention and work to public insurance in industrialised democracies. And many research themes are definitely of interest for normative thinkers.

\section{A Potential for Research}

A political philosophy of public insurance includes research avenues that are both theoretically and practically interesting. 
A central theme in the study of insurance in general and public insurance in particular is the role of individual responsibility and the forms it could take. Through risk pooling, insurance spreads on a community (policyholders or citizens) not only risks, but the material responsibility for these risks too. Thus it tends to relax the link between the causal, moral and material dimensions of responsibility. A common assumption for folk or conservative views on responsibility is to judge the individual who 'caused' a state of affairs by her actions (or maybe her absence of actions) as prima facie materially responsible for the adverse consequences. Often she is also held morally responsible. Insurance arguably breaks apart the following chain: causally responsible-materially responsible-(and perhaps) morally responsible (Landes 2013). And Marchman and Nielsen's paper proposes a discussion of the role of responsibility in public insurance and the welfare state.

Another theme is the role that public insurance should play in broader public policies, including redistributive devices. For example Robert Shiller's proposition to extend insurance to various domains such as education and university loans, future earnings (Shiller 2003) opens up interesting avenues. In relation to redistributive policies, a connected issue is the relation between insurance mechanisms and traditional welfare tools (such as means-tested devices). The aim would be not only to determine the scope of the part of redistribution that goes through insurance devices, but also the forms, content and justifications for such redistribution.

A third avenue is to discuss the redistributive implications of public insurance. These implications are obvious, especially when seen under the light of theories of justice based on the choices/circumstances distinction as in luck egalitarianism as illustrated by Knight's contribution. In fact, there is also room for investigating insurance beyond this redistributive aspect. Thus, insurance could be egalitarian in another sense, for instance by fostering equal status or consideration among policyholders or citizens (Anderson, forthcoming). In short, the question of which form of equality public insurance promotes or should promote is left open. Landes and Néron's contribution to the present issue explores this path.

A fourth research avenue is to contrast public and private insurance mechanisms. As previously noted, the study of early insurance arrangements, which were usually handled by fraternities, friendly societies or unions, shows a history of social support that develops outside public institutions. There is therefore a temptation to draw a normative distinction between spontaneous and centralised insurance schemes. Whether this position is convincing, it underlines the relation between a technology-insurance - and the entity that manages this technology-markets or states. A central issue is therefore also the proper definition of public insurance: is public insurance public only due to public management or is there any kind of thicker characteristic that distinguishes public from private insurance? This issue has institutional implications in terms of the division of spheres of competences between private and public devices in regard to various risks (socioeconomic, industrial, environmental, etc.).

A last avenue concerns public insurance as a form of social control or social regulation. As noted, insurance is about collectivising risks and expected losses. However, this risk-pooling process comes with informational problems, namely 
adverse selection and moral hazard. According to microeconomic textbooks, individuals have incentives to hide their real risk profile in order to pay lower premiums and policyholders tend to adopt riskier behaviours once insured. As a result, any insurance scheme must design tools and procedures for taming moral hazard and adverse selection like underwriting, monitoring policyholders' behaviour, reintroducing a dose of individual responsibility (through deductibles, coinsurance or co-payment), and so forth. This shows that insurance embodies a form of control. Insurance is not only a technology that pools individual resources together. In order to be efficient, it also requires an effective control exerted on policyholders or citizens. For public insurance, this raises questions such as: what are these controls? Which institution is in charge of controlling, following which rules and within what limits? This last research avenue clearly intersects with the literature on paternalism.

\section{The Current Context}

A few final words are needed in regard to the current political context. Reflections on public insurance from political philosophers could certainly be directly relevant for a number of current political debates. For instance, Daniel Weinstock evaluates the possible impact of the social determinants of health approach on public insurance. The current context of modern welfare states has two characteristics directly relevant for a political philosophy of public insurance: the decline of the industrial welfare state (if not materially, at least discursively) and the rise of inequalities.

The first characteristic is the decline of the welfare state. This decline is either material, meaning that public institutions are stripped of their traditional attributes, or discursive, in the sense that the legitimacy of the welfare state to undertake redistributive but also regulative activities is challenged. The second characteristic regards rising inequalities. The evidence is overwhelming (OECD 2011; Piketty 2014; Stiglitz 2013) that wealth is becoming more and more concentrated at the top of the income ladder. It seems natural that any political analysis on public insurance needs to take this context into account. A political philosophy of public insurance could help forge new, potentially better or at least supportive arguments in favour of a reduction of inequalities.

In this context, a political philosophy of public insurance may have at least three objectives. First of all, it may stress the importance of public insurance for any society that is based on equality to some degree. It could do this by showing that equality is ingrained in public insurance both in theory and practice. It could furthermore provide additional, egalitarian arguments regarding the distribution of goods and/or status.

Secondly, it could provide additional arguments in favour of state intervention and regulation. Of course such arguments may pertain to equality. But, they also could resort to efficiency. In short, the welfare state may be proved more efficient than markets to provide various goods and services. Following the work of some political theorists (Heath 2001; Moss 2002), it could be shown that state-based 
solutions are actually more efficient than market-based solutions for handling national health insurance, pensions or unemployment benefits. Indeed, arguments may be produced for why states exhibit superior efficiency as regards market failures, for committing future generations to insurance plans (such as pensions), for why they are more suitable for controlling and monitoring agents or have better resources for managing risks (e.g. dramatic demographic shifts or large catastrophes).

Thirdly, a political philosophy of public insurance directly engages with a central feature of recent reforms of the welfare state: the place of individual responsibility. In recent years, many reforms regarding public health insurance have consisted in the (re-) introduction of a dose of individual responsibility, by for example implementing some deductibles for physician consultations or drugs. These reforms may assume some kind of individual control over, and may rely on views about responsibility for, for instance, health outcomes. Philosophical considerations of individual responsibility may qualify debates over the conditions for health insurance in contemporary welfare states.

In short, political philosophers have many reasons to be more interested in public insurance than they currently are. Public insurance provides opportunities for refining our views on justice and equality. The institutional dimension of public insurance, i.e. its specific features as a cooperative mechanism, may be another reason why normative thinkers could be interested in the topic. Potential themes of research are legion and await careful scrutiny. But, maybe more importantly, public insurance is probably one of the fields (with redistribution and taxation) where political philosophy could in fact have a significant impact on the on-going reforms in industrialised states.

Acknowledgments We would like to thank Res Publica editors Philip Cook and Sune Læggard for their work on this special issue as well as the anonymous referee. This issue proceeds from a conference What Does the Welfare State Owe to Public Insurance? organised in June 2012 in Copenhagen with the support of the Danish Council for Independent Research [grant 10-080448].

\section{References}

Anderson, Elizabeth. Forthcoming. Thomas Paine's 'Agrarian Justice' and the origins of social insurance. In Ten neglected classics of philosophy, ed. Eric Schliesser, Oxford University Press.

Baker, Tom, and David A. Moss. 2009. Government as risk-manager. In New perspectives in regulation, ed. David A. Moss, and John Cisternino, 87-109. Cambridge: The Tobin Project.

Beck, Ulrik. 1992. Risk society: Towards a new modernity. London: Sage Publications.

Beito, David T. 2000. From mutual aid to the welfare state. Chapel Hill: The University of North Carolina Press.

Cordery, Simon. 2003. British friendly societies, 1750-1914. New York: Palgrave Macmillan.

Dworkin, Ronald. 2002. Sovereign virtue: The theory and practice of equality. Cambridge: Harvard University Press.

Ericson, Richard V., and Aaron Doyle (eds.). 2003. Risk and morality. Toronto: University of Toronto Press.

Ewald, François. 1986. L'État providence. Paris: Grasset.

Ewald, François. 1996. Histoire de l'État providence. Paris: Grasset.

Goodin, Robert E. 1988. Reasons for welfare: The political theory of the welfare state. Princeton: Princeton University Press.

Heath, Joseph. 2001. The efficient society. Toronto: Penguin Canada. 
Heath, Joseph. 2011. Three normative models of the welfare state. Public Reason 3: 13-43.

Landes, Xavier. 2013. The normative foundations of (social) insurance: Technology, social practices and political philosophy. Torino: Laboratorio di Politica Comparata e Filosofia Pubblica, Centro Einaudi.

Landes, Xavier. 2014. How fair is actuarial fairness? Journal of Business Ethics. doi:10.1007/s10551014-2120-0.

Lehtonen, Turo-Kimmo, and Liukko Jyri. 2011. The forms and limits of insurance solidarity. Journal of Business Ethics 103: 33-44.

Moss, David A. 2002. When all else fails: Government as the ultimate risk manager. Cambridge: Harvard University Press.

Néron, Pierre-Yves. 2010. Business and the polis: What does it mean to see corporations as political actors? Journal of Business Ethics 94: 333-352.

Norman, Wayne. 2012. Business as self-regulation: why principles that ground regulation should be used to ground beyond-compliance norms as well. Journal of Business Ethics 102: 43-57.

OECD. 2011. Divided we stand: Why inequality keeps rising. Paris: OECD Publishing.

Piketty, Thomas. 2014. Capital in the twenty-first century. Cambridge: Harvard University Press.

Shiller, Robert J. 2003. The new financial order: Risk in the 21st Century. Princeton: Princeton University Press.

Stiglitz, Jospeh E. 2013. The price of inequality: How today's divided society endangers our future. New York: W. W. Norton \& Company.

Stone, Deborah. 1999-2000. Beyond moral hazard: Insurance as moral opportunity. Connecticut Insurance Law Journal 6: 11-46.

Walzer, Michael. 1983. Spheres of justice. New York: Basic Books. 